\title{
Financial Distress Prediction Through Cash Flow Ratios Analysis
}

\author{
Amrizah Kamaluddin ${ }^{1}$, Norhafizah Ishak ${ }^{1} \&$ Nor Farizal Mohammed ${ }^{2}$ \\ ${ }^{1}$ Faculty of Accountancy, Universiti Teknologi MARA, Shah Alam, Malaysia \\ ${ }^{2}$ Accounting Research Institute, Universiti Teknologi MARA, Shah Alam, Malaysia \\ Correspondence: Amrizah Kamaluddin, Faculty of Accountancy, Universiti Teknologi MARA, Shah Alam, \\ Malaysia.
}

Received: April 20, 2019

Accepted: May 7, 2019

Online Published: May 19, 2019

doi:10.5430/ijfr.v10n3p63

URL: https://doi.org/10.5430/ijfr.v10n3p63

\begin{abstract}
The purpose of this study to examine the relationship of cash flow ratios in predicting financial distress companies, with industrial and consumer product companies in Bursa Malaysia as the sample. The study on financial distress is critical as it can lead to bankruptcy, which may adversely affect the economy of the country. Therefore it is worth exploring any indicators that can identify the possibility of financial distress in the company. The tools enable to address the potential problems that can mitigate from distressed financial position. Most prior studies in Malaysia focus on traditional financial ratios, while this study exploits the strength of cash flow ratios. The liquidity ratio, solvency ratio, efficiency ratio and profitability ratio utilized in this study are derived from the statement of cash flows. The Altman Z-score is used to measure the level of the financial distress. The findings show mixed relationships between solvency ratio and financial distress and a negative significant relationship between profitability ratio and financial distress, whilst efficiency ratio has no relationship with the financial distress. These results suggest that cash flow ratios are reliable tools to predict financial distress for Malaysian context. The study is useful in giving insights to the stakeholders in their decision making.
\end{abstract}

Keywords: financial distress, cash flow ratios, Malaysia

\section{Introduction}

Financial distress is one of preceding circumstance that leads the business into insolvency. Business failure and financial distress are common status quos happen in the competitive market environment. The financial distress problems arise when the companies have difficulties to pay the financial commitment (Khaliq, Altarturi, Thaker, Harun and Nahar, 2014; Roslan, 2014; Bae, 2012), have to maintain the high payment of fixed cost, low liquidity and uncertain revenue (Roslan, 2014; Hassan \& Alanazi 2018). The company is in the financial difficulties faced the cash flow problems or cash shortage in their operation when they are unable to generate sufficient cash to supersede the current obligation (Outcheva, 2007). Due to low cash flow state, the companies tend to violate their debt covenant towards their creditors (Purnanandam, 2008) and have a high tendency to lose significant of their market share (Opler and Titman, 1994).

When the company is heading to the financial distress, the chances of them to lead to bankruptcy are higher and this will bring bad reputation to the company. It is because, where the business is heading to financial distress, the potential of the shareholder to draw back their shares is higher, and also it might prevent potential shareholder from investing in the company (Khaliq et al., 2014).

The financial distress prediction has been attracting a great interest to researchers because of the importance of prediction towards potential and current investor, stock market regulators and also for the company itself (Alifiah, 2014; Bae, 2012) and the prediction is capable to provide a signal regarding the company's financial performance (Roslan, 2014).

The research on the financial distress prediction is still an imperative issue in the finance area. The issue of the financial distress and bankruptcy amongst the corporations had been discussed by scholars for many years attributable to the significance of the prediction that can capture the company's performance and the ability to maintain existence in the market (Altman, 1968; Bae, 2012; Bhandari and Iyer, 2013; Alifiah, 2014; Khaliq et al., 2014; Rim and Roy, 2014; Fawzi et al., 2015). Due to the present financial market exposure, it is crucial for the external users such as investors, creditors, investment advisors and other stakeholders to give an early warning 
regarding firms that heading to financial difficulties. Thus, it requires appropriate tools to identify the possibility of the financial distress in the company which enables to address the potential problems that can mitigate from distressed financial position.

Ratio analysis is a very unassuming method that has been practiced in evaluating the financial strength or weaknesses of the companies given that it can explicate the relationship among the items from the financial statement (Bhandari and Iyer, 2013). In most studies, it asserts that traditional financial ratios play an important role to determine the financial performance of the companies (Beaver, 1966; Altman, 1968; Rim and Roy, 2013; Alifiah, 2014; Khaliq et al., 2014). However, other studies found that the cash flow ratio provides dependable tool to predict financial distress of the companies (Ibarra, 2009; Bhandari and Iyer, 2013; Fawzi et al., 2015) since the cash flow ratio able to complement the traditional ratio by providing an additional information that manage to capture the firms' efficiency in financing their growth and also the ability to meet their financial commitment (Frank and Urbancic, 2005; and Ong et al., 2011).

In the financial statement, statement of cash flow is required to be prepared which provides the information of the cash inflow and outflow that can help users evaluating the firm's performance and future outlook as an addition to the evaluation on balance sheet (Frank and Urbancic, 2005). Financial statements consist of financial information that is mandatory to be disclosed in the annual report for each company. It consists of information on firm's financial performance and condition that show the strength or weaknesses of the company. Thus, it is essential to measure the company's performance based on the cash flow data since the balance sheet items are only able to measure at a single point of time whilst income statement are consist of many non-cash items. Only cash flow statement which record the changes from time to time and focus on the cash that is used in the operation of the company (Mill and Yamamura, 1998)

Hence, due to the strength of cash flow ratios and limited study in Malaysia that examine the cash flow ratios, they are used in this study as a purpose to envisage the financial distress amongst public listed establishments in Malaysia.

\section{Literature Review}

Beaver (1966), Altman (1968) and also Altman, Haldeman and Narayanan (1977) are among the pioneer scholars that discussed the subject of predicting financial distress. Andrade and Kaplan (1998) identify two situations of financial distress. Firstly, it happens when the company defaults their payment of debt. Secondly, if the company tends to restructure their debt in order to prevent the default situation. This might be an initial warning signal that the company is heading towards financial distress state of affairs. In other words, financial distress situation materializes the minute the company is incapable to fulfill the liabilities concerning their third parties. Their study in Indonesia finds that an increasing amount of non-performing loan by commercial banks and delisted public companies point to the common phenomenon of financial distress.

The distress situation can be worsened if the liquidity situation of the company is illiquid, the cost of the fixed expenses intensifies and when the revenue deteriorates especially during the economic downturn. The company in distress situation fundamentally will experience high cost due to some reasons. One of them is that their employee will turn out to be less productive, their anxiety will intensify and they will correspondently have inferior self-confidence as a consequence of the fear of losing their jobs. The state of affairs may perhaps turn out to be a disaster once the existing and prospective investor pulls back their investment thus reducing capital to run their operation and as the result company might go into liquidity or bankruptcy case (Bae, 2012; Khaliq et al, 2014; Hossain, Hossain \& Jahan 2018). Furthermore, the company will tend to incur more borrowings in order to strive in the market and this leads to the challenging scenario of having to fulfill the current and future commitment when they are in the distressed situation (Ward, 1994, Khaliq et al;., 2014).

In Malaysia's scenario, the companies facing the financial difficulties will be classified under Practice Note 17 (PN17) and Guidance Note 3 (GN3) by Bursa Malaysia (Smith, Syahrul and Ahmad, 2004; Adibah Wan Ismail, Adzrin Raja Ahmad, Anuar Kamarudin and Yahaya, 2005; Tew and Nordin, 2006; Zeni and Ameer, 2010). The companies under this categories will seek court protection against creditors because of the financial problems (Low, Fauzias, and Yatim, 2001; Ong et al., 2011). Usually, the court will restructure financial distress companies into the Scheme of Arrangement and Reconstruction under Section 176 to stop their creditors from chasing them (Zeni and Ameer, 2010; Ong et al, 2011, Fawzi et al, 2015; Hsiao, 2017). The statistic shows that significant number of companies from consumer and industrial product industries fall into PN17 status in the period of 2014 and 2015 (www.bursamalaysia.com). 
It is well-known fact that if the company in the financial distress status, it might influence and jeopardize the firm's value (Bae, 2012; Inusah, 2018 ).Therefore, it is crucial for the users such as investor, stakeholder, creditor and stock market regulators to assess the financial performance of the companies extensively and transparently in preventing them from incurring any losses in future (Alifiah, 2014). The evaluation of the financial performance fundamentally has been done from the analysis of the financial ratio given that it is capable to give a forecast of the financial distress and failure (Zeni and Ameer, 2010). The most famous article that discusses of the model to foresee bankruptcy is from the Professor Altman in his article in 1968 that uses multiple discriminant analysis (MDA) which derives data from the balance sheet and also income statement which is financial ratios to be included into his model called Altman Z-score model (Altman, 1968). Ever since, the model that consist of the financial ratio have been used by numerous researchers to predict the financial distress of the firms (Grice and Ingram, 2001; Tew \& Nordin, 2006; Ng, Wong and Zhang, 2011; Yi, 2012; Rim and Roy, 2013; Khaleq et al., 2014).

Nevertheless, there is a drawback of the financial ratios as the items are accrual based ratios. Most of the items are extracted from the balance sheet (reported only at single point of time) and income statement (non-cash items are included in the report such as depreciation and amortization) which are summarizing of the accounting records and it does not replicate the real liquidity position of the companies (Rodgers, 2011; Islam, et.al 2018). Since the balance sheet is reporting at a particular point of time which is historical data, the items can be inaccurate and lead to unfair analysis signal whilst cash flow statement reports the inflows and outflows of the cash for a given period of time. Due to nothing is more liquid than cash, only cash flow information is able to reflect the liquidity position of the companies. As for Ward (2011) indicate that there are two components in the cash flow statement that able to predict financial distress which is cash flow from operating. From that reason, it is proved that the cash flow ratio able to be the indicator that can be used as a predictor of the financial distress and ultimately in predicting the bankruptcy situation. This is because the cash information can be used to value the quality of earnings and also the financial elasticity in such companies (Mills and Yamamura, 1988).

Moreover, cash flow ratios are able to quantify the success of the company since the survival and growth can be determined by the capacity to generate cash into business (Rhyn, 1989). If there is inadequate cash generated from the operation, it can lead to financial distress as they are incapable to pay financial obligations that lead to default in payments (Bhandari and Iyer, 2013). In addition, the cash flows ratios can be used as extra information in the analysis that can complement the traditional ratio in order to deliver the clearer picture of the financial performance in the company. It can be more valuable if all information can be used together (Carslaw and Mills, 1991). The usefulness of the cash flow statement can be utilized when the users are able to analyze the different cash flow ratio from the statement. Thus, it will enhance their understanding towards the information provided in the statement. The cash flow ratio is more reliable for investors and lenders to complement the information contained in a traditional working capital ratio such as current ratio and quick ratio to capture the ability of a company to meet their payment of commitments when due (Mills and Yamamura, 1998). Ibarra (2009) states that the cash flow ratios are more influential to capture the performance of the business because if there is inadequate cash from the operation, the chances of the company heading to financial distress are greater.

Since financial distress is a very important indicator to the stakeholders and prior literature indicate that cash flow ratios are powerful in indicating financial distress and significant number of companies from consumer and industrial products in Malaysia are classified as financial distress, it motivates this study to investigate further the issue of financial distress and cash flow ratios in the context of Malaysia. Therefore, the purpose of this paper is to examine whether there are relationships between cash flow ratios and financial distress. Investigating this issue is important as the findings of this study provide help to the users, analysts and regulators in their decision making. The result from this study can also be used by an auditor in order to determine the going concern basis of the company in their audit process. Additionally, the result of this study can be used as additional information to expand the validity of the theory that can be used in predicting the financial distress.

\section{Hypotheses Development}

Bankruptcy theory begins with the recognition of bankruptcy systems which involves a necessary action that has to be taken to solve problems between the insolvent firms with the creditors. Financial distress is similar to insolvency. The distress arises when the company is unable to generate sufficient cash to cover the financial obligations (Schwartz, 2005). When they are unable to meet an agreement with creditors, the firms in financial distress are basically under an intermediate state towards the bankruptcy level. They may experience losses such as losing their loyal customers, valuable suppliers and also their important employees (Purnanandam, 2008). 
Myers (1977) describes that financial distress firms often suffer with liquidity problems that force them to lengthen the period of time to exit from the financial difficulties. They have to maintain sufficient cash to pay their employees, suppliers and other stakeholders even though they are in a financial distressed situation. The situation may become worse if they have to finance the project that has positive net present value. Hence, it is crucial for them to attract new capital into their companies to survive in the market and to improve the investment efficiency. Due to the problem of the debt overhang that faced in the financial distress firms, it is difficult for them to raise funding from the financial institution since there is a risk involved by them if the company unable to pay the commitment. Hence, it is more difficult for them to attract new sources of funding into the company. Consequently, the chances of financial distressed firm heading to bankruptcy are higher due to difficulties of getting new funding to maintain their operations (Senbet and Wang, 2010).

The users of financial statements such as creditors are observing for the liquidity ratios in their analysis as it can give the information whether the cash flow from operation is able to cover the short-term obligation (Ibarra, 2009; and Fawzi et al., 2015). Bhandari and Iyer (2013) affirm that if the company have an inferior value of liquidity ratio which is measured by operating cash flow divided by current liabilities, the probability of business failure are greater. It also have been validated in the study of Khong et al. (2015) when the liquidity cash flow ratio is one of the variables which is significant in anticipating the corporate failure in Malaysia.

The companies that have inadequate cash from the operating activities to pay the financial obligation in the long term run have difficulties to pay interest of the loan agreement and have a tendency to inflate their revenues can be considered as high leverage companies. Consequently, the tendency of them heading to financial distress is higher (Ibarra, 2009; Bhandari and Iyer, 2013; Fawzi et al., 2015). Hence, it is vital to appraise the solvency ratio given that this ratio is able to evaluate the financial strength of the companies such as the capacity to cover their interest obligation over the entire debt (Carlslaw and Mills, 1991; Mills and Yamamura, 1998; Bhandari and Iyer, 2013). In addition, Ong et al. (2011) find that cash flow to total debt is one of the significant predictors in predicting corporate failure in Malaysia. An efficiency ratio displays on how well the companies utilize their assets to generate a cash flow in their operation (Frank et al., 2005). This ratio is beneficial to both internal and external users (Ibarra, 2009) since it can capture the effectiveness of the company in utilizing their asset to stay away from the financial difficulties (Khong et al., 2015; Jr \& Peñol 2018). Profitability cash flow ratio is more appropriate to measure the firm's operating profitability more accurately than accrual accounting based profit ratio since this ratio calculate the company's capability to convert their sales into cash (Ibarra, 2009; Bhandari and Iyer, 2013; Fawzi et al., 2015). Fawzi et al. (2015) in their study find that profitability ratio has a significant relationship with the financial distress.

Based on the line of reasoning above, the subsequent hypotheses are developed:

H2 There is a relationship between the cash flow ratios and financial distress.

H2a: There is a relationship between the liquidity ratio and financial distress.

$\mathrm{H} 2 \mathrm{~b}$ : There is a relationship between the solvency ratio and financial distress.

H2c: $\quad$ There is a relationship between the efficiency ratio and financial distress.

H2d: $\quad$ There is a relationship between the profitability ratio and financial distress.

The following is the research framework that explains the analysis.

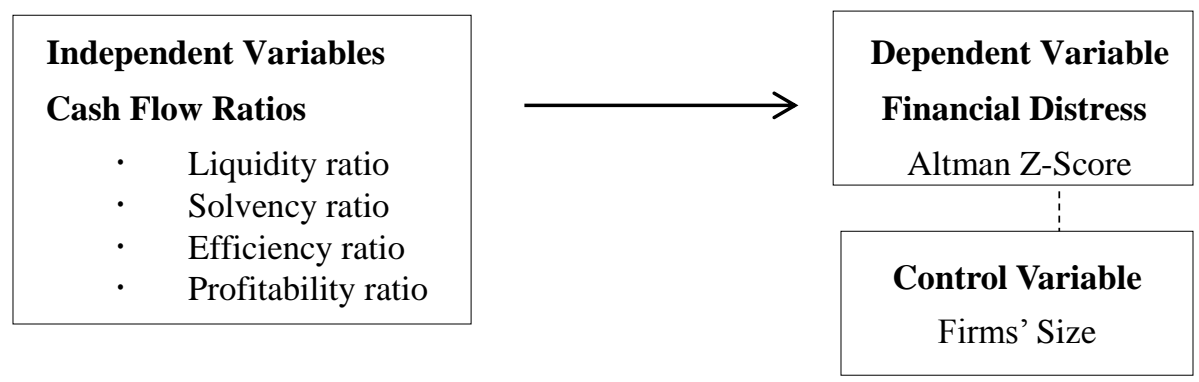

Figure 1. Research framework 


\section{Research Design and Methodology}

The data collection procedure started with the collection of the data from the annual reports. The annual report is selected as primary sources to collect the cash flow data due to the accessibility and widely coverage information that contained in the report. Annual report contains important sources to many users especially investors in the decision-making process. It is because the information in the annual report can be used by them to forecast the firm's performance.

Most of the data were collected and obtained from the OSIRIS. Then, the data that collected from the OSIRIS was cross-checked with the annual report in order to enhance the reliability and validity of the information. Any missing data in the OSIRIS was later collected from the annual report. The data of the selected companies are accessible on Bursa Malaysia website at http://www.bursamalaysia.com/market/. The method used is consistent with the preceding studies that were done by Khong et al., (2015); Fawzi et al., (2015); Khaliq et al., (2014); Bhandari and Iyer (2013) and Ong et al., (2011). The company is chosen based on the stratified sampling method. Sekaran and Bougie (2013) define a stratified sampling as a process that involves of segregation from the total population and followed by random selection of the subject for each layer. This technique is used because this study tends to highlight an industrial and consumer product companies within the total population of listed companies in Bursa Malaysia. Thus, it is beneficial to make sure the specific industries selected are present within the sample. According to Sekaran and Bougie (2013), 20 percent of the sample for each stratum considered as sufficient in conducting the research.

Table 1 shows the calculation of proportionate stratified random sampling for the industrial and consumer product industries:

Table 1. Calculation of proportionate stratified random sampling

\begin{tabular}{lll}
\hline Industry & Number of companies & Proportionate sampling \\
\hline Industrial product & 242 & $20 \%$ × 242 $=48$ \\
\hline Consumer product & 130 & $20 \%$ x $130=26$ \\
\hline Total & $\mathbf{7 4}$ x 2 years $=\mathbf{1 4 8}$ & \\
\hline
\end{tabular}

This study is set to use 80 companies from the industrial and consumer product ranging from a period 2014 until 2015 on order to satisfy the proportionate sampling calculation. Hence, this sample is sufficient as suggested by Sekaran and Bougie (2013).

\subsection{Measurement of Variables}

\subsubsection{Measurement of Financial Distress}

The dependent variable is the main attention since it is in line with the objective in this study. The financial distress which is proxied by Altman Z-score was used as the dependent variable for this study. This model was developed by Professor Edward I. Altman in 1968 that can impart some thoughts regarding financial reliability of the company as for whether they are performing well or not. This model has been mentioned by various researchers in their study including Khaliq et al. (2014), Rim and Roy (2013), Wang (2012) and Ng et al., (2011). However, due to the constraint of the original model which is share price data that only applicable for the publicly manufacturing company, Altman had revised the model in 1983. This new model is appropriate for the private manufacturing firms.

Altman (1983) defined the distress function into:

$$
Z=0.717 X 1+0.847 X 2+3.107 X 3+0.420 X 4+0.998 X 5
$$

Where:

X1 = Working Capital / Total Assets

$\mathrm{X} 2=$ Retained Earnings $/$ Total Assets

$\mathrm{X} 3$ = Earnings before Interest and Taxes / Total Assets

$\mathrm{X} 4$ = Book value of Equity / Total Liabilities

X5 = Sales / Total Assets

The figure from the Z-score is able to categorize whether the company is financial distressed or non-financial distressed. Table 2 shows the descriptions of the category according to the model: 
Table 2. Description of category in the Altman Z-score model

\begin{tabular}{ll}
\hline Range of Z-score & Interpretation \\
\hline Above than 2.99 & $\begin{array}{l}\text { The companies are well performed and being in a good position that safe from } \\
\text { financial difficulties }\end{array}$ \\
\hline Between 2.99 and 1.23 & $\begin{array}{l}\text { It considered as a grey area because it give a warning sign that the company } \\
\text { have a chances to the financial distress situation that might turn into bankruptcy } \\
\text { problem }\end{array}$ \\
\hline Less than 1.23 & $\begin{array}{l}\text { It is considered as bad indication since the company is in financial difficulties } \\
\text { and the chances heading to bankruptcy are higher. The action have to be taken } \\
\text { in order to prevent more serious financial problems occur. }\end{array}$ \\
\hline
\end{tabular}

\subsubsection{Measurement of Independent Variables}

An independent variable is the variable used to influence the dependent variable. In this study, the cash flow ratios which is solvency, liquidity and efficiency ratio denoted as independent variables. Liquidity ratio is being used as a first predictor in this study. This ratio is being used to determine the ability of the company in meeting their short-term obligation (Ibarra, 2009; Fawzi et al., 2015). The liquidity ratio used in this study are cash flow from operating activities to current liabilities (CFFO/CL) (Ryu and Jang, 2004; Ibarra, 2009; Rodgers, 2011 and Fawzi et al., 2015). The second predictor in this study was solvency ratio. According to the Hotchkiss (1995) solvency is the condition that the company being solvent. Fawzi et al. (2015) explain solvency ratio used to measure the ability of the company to meet long-term obligation.

In this study, the solvency ratio is measured by cash flow interest coverage which is determined by the cash flow from operation plus interest divided by interest (CFFO + INT / INT) (Ryu and Jang, 2004; Ibarra, 2009; and Fawzi et al., 2015), cash flow from operating to total liabilities (CFFO / TL) (Ryu and Jang, 2004; and Fawzi et al., 2015) and cash flow from operating activities to long-term liabilities (CFFO / LTL) (Ibarra, 2009; and Fawzi et al., 2015). Thirdly, the efficiency ratio is being used as the third predictor in this study. Efficiency ratio is used to measure the ability of the company in utilizing their assets (Ibarra, 2009; and Fawzi et al., 2015). Cash flow from operating activities to fixed assets (CFFO / FA) (Ibarra, 2009; and Fawzi et al., 2015) is used in this study as proxy to the efficiency ratio.

The last predictor in this study would be the profitability ratio. This ratio is calculated to measure whether the company able to generate enough return on their investment. Profitability ratio can also be utilized to determine the level of the accomplishment and failure of the company (Ibarra, 2009).Cash flows from operating activities divided by net income (CFFO / NI) (Ibarra, 2009; Fawzi et al., 2015) is used as to measure the profitability ratio in this study. Firm size is used as proxy for the control variable in this study. The firm size is measured by the aggregate assets of the company. The measurements used are constant with the study from Akhigbe and Martin (2008).

\section{Data Analysis and Discussion}

The background of the company as per Table 3 exhibits that there are two industries involved in this study which is consumer and industrial product industries that ranged from 2014 until 2015. To begin with, there are 80 companies included in this study which can contribute to the 160 samples. However, the numbers of the samples are reduced to 150 due to exclusion of the outliers when normality test was performed. From the Table 3, it shows that there are 65 samples (43.3 percent) from the consumer product industry and 85 samples (56.7 percent), contributed from the product industry. This sample is sufficient as suggested from Sekaran and Bougie (2013) in the table of proportionate sampling.

Table 3. Descriptive statistics for the company background

\begin{tabular}{lll}
\hline Industry & Frequency & Percentage \\
Consumer product & 65 & 43.3 \\
Industrial Product & 85 & 56.7 \\
Total & 150 & 100 \\
\hline
\end{tabular}




\subsection{Descriptive Statistics}

Table 4 shows the descriptive statistics for the consumer and industrial product industries according to the Altman Z-Score classification as per Table 4 in chapter 3. From the Table 4, it shows that most of the companies from both industries fall under grey area classification which contributed 82 sample sizes. It is followed by 42 samples are in the healthy area whilst 28 samples in bankrupt.

Table 4. Descriptive statistics for the industries according to Altman Z-Score classification

\begin{tabular}{llll}
\hline Industry & Healthy & Grey & Bankrupt \\
\hline Consumer product & 17 & 35 & 13 \\
\hline Industrial Product & 23 & 47 & 15 \\
\hline Total & 40 & 82 & 28 \\
\hline
\end{tabular}

The dependent variable is presented by Altman Z-Score as proxy of financial distress. Table 5 below is the details for the description of the dependent variable. The mean for dependent variable was 0.3347 . For the minimum value, the statistics signifies that the value is at negative which is -0.66 whilst the maximum value for Altman Z-Score was 1.26. The negative value in the minimum statistics indicates that the sample companies are in financial difficulties and the chances heading to bankruptcy are higher for the period 2014 until 2015. The action has to be taken in order to prevent more serious financial problems occur. It is consistent with the judgment from the Shriram (2015) that consumer and industrial product industry had teething troubles for the period 2014 until 2015 that lead to the deficits for both industries. However, the standard deviation for the Altman Z-Score is 0.29 which is likely at a lower value and close to the mean value of 0.33 .

Table 5. Descriptive statistics for financial distress

\begin{tabular}{lllllll}
\hline & $\mathrm{N}$ & Range & Minimum & Maximum & Mean & Standard \\
\hline Altman Z-Score & 150 & 1.92 & -0.66 & 1.26 & & Deviation \\
\hline
\end{tabular}

There are four independent variables that are used in this study as proxies for the cash flow ratios which is liquidity ratio, solvency ratio, efficiency ratio and profitability ratio. The Table 6 below shows the list of grouping ratios employed for the independent variables:

Table 6. Grouping of cash flow ratios (Please refer to section 4.1.2 for the denotation of variables)

\begin{tabular}{ll}
\hline Ratio & Measurement \\
\hline Liquidity & CFFO / CL \\
\hline Solvency_1 & CFFO + INT / INT \\
\hline Solvency_2 & CFFO / TL \\
\hline Solvency_3 & CFFO / LTL \\
\hline Efficiency & CFFO / FA \\
\hline Profitability & CFFO / NI \\
\hline
\end{tabular}

The first proxy used is liquidity ratio that measured by calculating CFFO / CL. This ratio is suitable in detecting whether there is adequate cash from the operating activities to settle up current debts (Ibarra, 2009). Table 7 put on view that the liquidity ratio is ranged from -2.14 to 0.67 . Negative figure in minimum value indicated that the company did not generate sufficient cash from the operation.. This also results from the fact that the company's 
current liabilities are higher which cannot be funded by using the cash from the operation. The company is in the liquidity difficulties with a negative cash flow from operation since the mean value $(-0.6)$ and standard deviation $(0.6)$ are in a considerable range

The second proxy for the cash flow ratio is solvency ratio. There are three ratios tested under solvency ratio which is solvency_1, solvency_2, and solvency_3. As for the solvency_1, this ratio measures the company's capacity to settle the interest from entire debt. Table 7 shows that the minimum value is -1.4 which indicate that the company also has problems in generating cash from the operation. Hence, the company has fewer resources to meet the interest payment that could bring the legal action from their creditors. In addition, the maximum value of 3.94 indicates marginally higher differences with the minimum value maybe due to the trivial amount of interest paid by the company compared to the amount of cash generated from the operation (Billah et al., 2015). However, the mean and standard deviation value for the solvency_1 are the same value, 0.85 . The ratio of solvency_2 is more reliable in measuring the solvency since it is dedicated to the payment of debt by the company's (Mills and Yamamura, 1998). The minimum and maximum value for the solvency_2 are -2.15 and 0.43 respectively. This specifies that the companies have a limited value of the cash generated from the operation to cover their total debt. The companies can be categorized in the solvency problems with a negative cash flow from operation since the mean value $(-0.72)$ and standard deviation (0.59) are in a large range. The minimum and maximum value for the solvency_3 are -1.52 and 2.74 respectively. Again, the firms have the lack of ability to meet the long-term obligation from the cash generated from operation activities. However, the standard deviation for the solvency_3 is 0.13 which is likely at a lower value and close to the mean value of 0.73 .

The third proxy for the cash flow ratios is efficiency ratio. In this study, efficiency is being measured by CFFO / FA which indicates the percentage of generating cash in the operation by using the fixed asset (Ibarra, 2009 and Fawzi et al., 2015). Table 7 shows the minimum value is -2.82 and the maximum value is 0.15 explained that the company is ineffective in utilizing their asset in generating cash to the companies due to marginally high volatility range of the values. This may be due to old fixed assets that are used in the operation that effect the companies' efficiency which steers to the cash difficulties in the operational activities. The mean and standard deviation value are -0.87 and 0.52 respectively.

The profitability is being measured by CFFO / NI in this study as the last proxy for cash flow ratios. It measures the collectivity of the net income that can be converted into the cash (Fawzi et al., 2015). From Table 7, it is shown that the minimum value for profitability is -2.02 which indicate the company underwent loss for the year 2014 and 2015 . While the maximum value for profitability is 1.54 . The company are in the struggling situation to translate their net income into cash with a negative cash flow from operation since the mean value $(-0.01)$ and standard deviation $(0.49)$ are in a large range.

Table 7. Descriptive statistics for cash flow ratios

\begin{tabular}{lllllll}
\hline & $\mathrm{N}$ & Range & Minimum & Maximum & Mean & Standard \\
\hline & & & & & & Deviation \\
\hline Liquidity & 150 & 2.81 & -2.14 & 0.67 & -0.61 & 0.5999 \\
\hline Solvency_1 & 150 & 5.35 & -1.4 & 3.94 & 0.85 & 0.8575 \\
\hline Solvency_2 & 150 & 2.58 & -2.15 & 0.43 & -0.72 & 0.5924 \\
\hline Solvency_3 & 150 & 4.27 & -1.52 & 2.74 & 0.13 & 0.7311 \\
\hline Efficiency & 150 & 2.97 & -2.82 & 0.15 & -0.87 & 0.5242 \\
\hline Profitability & 150 & 3.56 & -2.02 & 1.54 & -0.01 & 0.4962 \\
\hline
\end{tabular}

The control variable in this study is presented by the firm size. The total assets are being used as a proxy for company size. The descriptive statistics analysis is presented in Table 8 below. From the Table 8 , the statistics show that the mean value of the total assets was RM 5.417 million, the minimum value was RM 4.37 million and the maximum value was RM 6.58 million. The standard deviation for the company's size is RM 0.51 million which is likely at a lower value. This indicates that the value of the total assets is close to mean value. 
Table 8. Descriptive statistics for control variable

\begin{tabular}{lllllll}
\hline & $\mathrm{N}$ & Range & Minimum & Maximum & Mean & Standard \\
\hline & & & & & & Deviation \\
\hline Size & 150 & 2.21 & 4.37 & 6.58 & 5.417 & 0.5097 \\
\hline
\end{tabular}

The normality can be defined in the way of describing symmetrical, bell-shaped curve, and also have the greatest frequency of scores in the middle with smaller frequency towards the extreme (Gravetter \& Wallnau, 2000). In this study, the normality has been measured by looking at skewness and kurtosis value. The result of the normality test in this study after the exclusion of outliers and transformation of the data are consistent with the study of Pallant, (2011) and Brown, (2012).

\subsection{Correlation Analysis}

Correlation analysis is used to determine the strength together and also the direction for a linear relationship that arose between two variables (Pallant, 2005). Table 9 reports that there is high value of correlation for the liquidity and solvency_2 variables. There are four items that have a high relationship with the liquidity variables which is solvency_1 (50.4 percent), solvency_2 (98.8 percent), solvency_3 (64.9 percent) and efficiency (74.8 percent). Whilst, for the solvency_2 variables, there are two relationships with this variable indicate the correlation value of more than fifty percent which is solvency_3 (73.4 percent) and efficiency (77.3 percent). Hence, this correlation value can justify on the multicollinearity problems for the liquidity and solvency_2 variables which the Variance Inflation Factor (VIF) value is more than 10 indicates the existence of multicollinearity when the predictors in a regression model are highly correlated. Multicollinearity problems can be detected by looking at the VIF value. If the values are less than 10, it indicates that there are no multicollinearity problems which can affect the regression analysis which the results can be biased (Pallant, 2005). Due to that, the liquidity and solvency_2 variables have been dropped in this study as the existence of the multicollinearity problems as suggested in the study of Fawzi et al., (2015).

Table 10 shows the result of correlation analysis after exclusion of two variables which are liquidity and solvency_2 due to the multicollinearity problems. There is no multicollinearity problem which all variables shows the VIF value less than 10. Table 10 reports that the variables which resulted in high and positive significant correlations between two variables at 1 percent level were between efficiency and solvency_3 at 66.1 percent followed by Altman Z-Score and solvency_3 at 48.3 percent. This is followed by solvency_3 and solvency_1 with 45.7 percent, profitability and efficiency at 42 percent, efficiency and solvency_1 at 41 percent and size with the solvency_1 at 33.2 percent. In addition, profitability and solvency_1 show positive significant correlation at 5 percent level. Whilst, the relationship between Altman Z-Score with solvency_1 (18.7 percent) and Altman Z-Score with efficiency (17.1 percent) have a positive significant correlation at 10 percent level. As for the size variables, it had no significant relationship between the solvency_3 (-7 percent), efficiency (-3.6 percent), profitability ( -0.9 percent) and Altman Z-Score ( -9.5 percent). There is no significant relationship between Altman Z-Score with profitability and also size at -9.5 percent for both variables. Lastly, there is no significant relationship between profitability and solvency_3 at 7.2 percent. To summarize, as it shows a low correlation between dependent and independent variables, there is no multicollinearity problem.

Table 9. Correlation analysis before detected multicollinearity problems

\begin{tabular}{lllllllll}
\hline & LIQ & SOLV_1 & SOLV_2 & SOLV_3 & EFFI & PROFIT & ALTMAN & SIZE \\
\hline LIQ & 1 & & & & & & & \\
\hline SOLV_1 & $.504^{* * *}$ & 1 & & & & & & \\
\hline SOLV_2 & $.988^{* * *}$ & $.523^{* * *}$ & 1 & & & & & \\
\hline SOLV_3 & $.649^{* * *}$ & $.457^{* * *}$ & $.734^{* * *}$ & 1 & & & & \\
\hline EFFI & $.748^{* * *}$ & $.410^{* * *}$ & $.773^{* * *}$ & $.661^{* * *}$ & 1 & & & \\
\hline PROFIT & $.213^{* *}$ & $.263^{* *}$ & $.211^{* *}$ & .072 & $.420^{* * *}$ & 1 & & \\
\hline ALTMAN & $.453^{* * *}$ & $.187^{*}$ & $.495^{* * *}$ & $.483^{* * *}$ & $.171^{*}$ & -0.095 & 1 & \\
\hline SIZE & $-.130^{*}$ & $.332^{* * *}$ & $-.126^{*}$ & -.070 & -.036 & -0.009 & -0.095 & 1 \\
\hline Alf & & & & & & & & \\
\hline
\end{tabular}

Notes: All p-value are two-tailed. $* * *$ Correlation is significant at the 0.01 level; **Correlation is significant at the 0.05 level; and *Correlation is significant at the 0.10 level 
Table 10. Correlation analysis after exclusion of variables that have multicollinearity problems

\begin{tabular}{lllllll}
\hline & SOLV_1 & SOLV_3 & EFFI & PROFIT & ALTMAN & SIZE \\
\hline SOLV_1 & 1 & & & & & \\
\hline SOLV_3 & $.457^{* * *}$ & 1 & & & & \\
\hline EFFI & $.410^{* * *}$ & $.661^{* * *}$ & 1 & & & \\
\hline PROFIT & $.263^{* *}$ & .072 & $.420^{* * *}$ & 1 & & \\
\hline ALTMAN & $.187^{*}$ & $.483^{* * *}$ & $.171^{*}$ & -.095 & 1 & \\
\hline SIZE & $.332^{* * *}$ & -.070 & -.036 & -.009 & -.095 & 1 \\
\hline
\end{tabular}

Notes: All p-value are two-tailed. $* * *$ Correlation is significant at the 0.01 level; **Correlation is significant at the 0.05 level; and *Correlation is significant at the 0.10 leve

\subsection{Regression Analysis}

Regression analysis is one of the parametric techniques that is used to analyze the data. In this study, multiple regression analysis is used to test the linear relationship between one dependent variable with two or more independent variables. Multiple regression analysis is able to provide more consideration to user's vis-à-vis the interrelationship between variables compared to correlation (Pallant, 2005). The model is established to test the hypotheses in this study which is to investigate the relationship between cash flow ratios and financial distress.

$$
\text { Distress }=\beta 0+\beta 1 \text { SOLV } \_1+\beta 2 \text { SOLV } \_3+\beta 3 \text { EFFI }+\beta 4 \text { PROFIT }+\beta 5 \text { SIZE }+\varepsilon
$$

Table 11 below presents the multiple regression results for testing the hypotheses in this study. Result in Table 11 presents that the value of R-square is 0.338 , df $(5,69)=7.050, \mathrm{P}<0.01$. This indicates that the independent and control variables contributed about 33.8 percent to financial distress. The result in Sig. F change value of .000 indicates that this study able to give statistically significant contribution. The results in Table 11 show that financial distress had no significant relationship with solvency_1 (.718), efficiency (.262) and size of the company (.119). However, solvency_3 showed a significant positive result at 1 percent significant level whilst profitability ratio showed a significant negative result at 5 percent significant level with the financial distress.

Table 11. Regression results

\begin{tabular}{llll}
\hline \multicolumn{4}{l}{ Standardized } \\
\hline & Coefficients & t-statistics & p-value \\
\hline Variables & Beta & & \\
\hline SOLV_1 & & & \\
\hline SOLV_3 & -0.039 & -0.363 & 0.718 \\
\hline EFFI & 0.638 & 4.78 & $0.000^{* * *}$ \\
\hline PROFIT & -0.153 & -1.131 & 0.262 \\
\hline SIZE & -0.235 & -2.185 & $0.032^{* *}$ \\
\hline R square & -0.168 & -1.578 & 0.119 \\
\hline$R^{2}$ change & & & 0.338 \\
\hline F-value & & & 0.338 \\
\hline Df & & 7.050 \\
\hline
\end{tabular}

***Correlation is significant at the 0.01 level (2-tailed)

***Correlation is significant at the 0.05 level (2-tailed)

The hypotheses in this study are to test whether there is a relationship between the cash flow ratios and financial distress. After exclusion of variables that have a multicollinearity problem, the proxies for the cash flow ratios are solvency ratio (solvency_1 and solvency_3), efficiency ratio and profitability ratio. The hypotheses of H2a which is 
whether there is a relationship between the liquidity ratio and financial distress cannot be tested and rejected since the liquidity ratio are being dropped in this study due to multicollinearity problems and it is consistent with the study of Fawzi e al. (2015). Hypotheses H2b, stated that there is a relationship between the solvency ratio and financial distress. There are two ratios that used to test the hypotheses for solvency ratio which is solvency_1 and solvency_3. Table 11 exhibited that solvency_1 has a negative insignificant relationship with the financial distress (coefficient value $=-0.039, \mathrm{t}$ values $=-0.363, \mathrm{p}$-value $=0.718$ ). Thus, there is no relationship between solvency_1 with financial distress.

Whilst, for the second ratio which is solvency_3, Table 11 exhibit that the coefficient value is 0.638 , t values is 4.78 and p-values are 0.000 . This indicates that solvency_3 has a positive significant relationship with the financial distress at 1 percent level. It can be explained that the company tends to obtain outside sources to finance their long-term liabilities when they have a negative cash flow from operating activities. An additional source should be used for company's daily operation activities and should not be used for financing the long-term debt. If this situation remains for a lengthier period, the tendency of the company's to fall into financial distress situation are higher (Fawzi et al., 2015). Thus, there is a relationship between solvency_3 with financial distress. It can be concluded that there is a mixed relationship between the solvency ratios and financial distress.

The hypotheses $\mathrm{H} 2 \mathrm{c}$ posit that there is a relationship between the efficiency ratio and financial distress. Based on results exhibited in Table 11, there is a negative and insignificant relationship between the efficiency ratios with financial distress whereby the coefficient values is -0.153 , $\mathrm{t}$ values is -1.131 and $\mathrm{p}$-value are 0.262 . This study finds that efficiency ratio has no relationship with the financial distress. Hence, the hypotheses of $\mathrm{H} 2 \mathrm{c}$ are not supported. These results are consistent with Fawzi et al. (2015) which found there is no relationship between the CFFO/FA with financial distress. The last sub-hypotheses for second hypotheses which are $\mathrm{H} 2 \mathrm{~d}$ state that there is a relationship between profitability ratio and financial distress. Table 11 shows that the coefficient value is $-0.235, \mathrm{t}$ value is -2.185 and p-value is 0.032. It indicates that there is a negative significant relationship between the profitability ratios with the financial distress at 5 percent level. It can be explained that the company is likely to face financial distress if the increase in the collectivity of net income is not converted into an increase in cash (Ibarra, 2009; Fawzi et al., 2015). Thus, the hypotheses of $\mathrm{H} 2 \mathrm{~d}$ are supported since there is a relationship between profitability ratios with financial distress.

In conclusion, the findings of this study indicate that solvency_3 (CFFO/LTL) are the most significant predictors of financial distress at 1 percent level. Meanwhile, profitability ratio (CFFO/NI) is significant at 5 percent level. The results explained that there is a relationship between the cash flow ratios and financial distress at 1 percent level as stated in appendix 1.2 (ANOVA, Model 2). Thus, hypotheses H2 are supported.The findings showed the results on the relationship between cash flow ratios as proxies by liquidity ratio, solvency ratio, efficiency ratio and profitability ratio with financial distress. Table 12 below summarizes the explanation above.

Table 12. Summary of hypotheses and the results of this study

\begin{tabular}{lll}
\hline No & Hypotheses & Results \\
\hline $\mathrm{H} 2$ & There is a relationship between the cash flow ratios and financial distress. & Accepted \\
\hline $\mathrm{H} 2 \mathrm{a}$ & There is a relationship between the liquidity ratio and financial distress. & Dropped \\
\hline $\mathrm{H} 2 \mathrm{~b}$ & There is a relationship between the solvency ratio and financial distress. & Partially Accepted \\
\hline $\mathrm{H} 2 \mathrm{c}$ & There is a relationship between the efficiency ratio and financial distress. & Not Accepted \\
\hline $\mathrm{H} 2 \mathrm{~d}$ & There is a relationship between the profitability ratio and financial distress. & Accepted \\
\hline
\end{tabular}

\section{Conclusion}

The objective of this study is to examine the relationship between cash flow ratios with financial distress. The study is carried out by using 150 data as a sample size which is gathered from the consumer and industrial product companies listed on Bursa Malaysia. The period covered is from 2014 to 2015. Although the prediction of financial distress had been deliberated by numerous researchers from various countries, there is an absence of preceding studies that concentrated on the cash flow ratios as a basis of measurement towards financial distress. There are two ratios that display a significant relation with the financial distress which is CFFO/LTL (solvency ratio) and CFFO/NI (profitability ratio). CFFO/LTL (solvency) is a significantly positive relationship at 1 percent level whilst CFFO/NI 
(profitability) is significantly negative at 5 percent level. The liquidity ratio (CFFO/CL) is dropped in this study due to multicollinearity problems. The other ratios, namely CFFO+INT/INT and CFFO/FA show an insignificant negative relationship. This indicates that efficiency ratio had no relationship with financial distress whilst solvency ratio has a mixed relationship on financial distress. Thus, it can be concluded that solvency and profitability cash flow ratio have a relationship with the financial distress. As for the control variable, the result shows that there is no relationship between the firms' size with financial distress.

This study contributes to the existing literature on the measurement of the financial distress prediction by using the cash flow ratios as a predictor. By understanding this relationship, these facts can assist various users such as managers, shareholder, investor, creditor, financial institution and auditor in assessing the firms' financial performance whether they are in good position or not. This analysis is important to the investor and shareholder in view of the fact that it can provide upcoming direction for them whether to keep investing in such businesses or not which may avoid colossal losses in the future. The investors and shareholders are the most affected parties when the company is in financial distress and heading to bankruptcy, considering that they had invested a huge amount of cash. Creditors and financial institutions may use the findings in this study to evaluate the ability of the company's to meet their commitment before they grant the loan and credit facilities. It is essential for them to evaluate the firms' financial performance since there are testimonies that the companies in financial distress were incapable to obligate their loan facilities. The study on the financial distress prediction would be useful for the managers as it can give an idea from the findings to make a corrective and prevention planning to evade the company from the financial complications. The managers can use the results from the finding to find and upheld the weaknesses of the companies in order to sustain the companies' continued existence in the markets. This study is also would be beneficial for an auditor as they can exercise the findings of this study to evaluate the going concern status of the current and future companies that they would like to investigate. It is because the going concern status and financial distress are narrowly related.

Despite the strengths, this study is not without its limitations. This study is only focusing on the cash flow ratios as an independent variable to predict the financial distress. In other words, this study is focusing on quantitative variables only without including qualitative variables such as leadership and type of ownership as a predictor for the financial distress prediction. The combination of the quantitative and qualitative variables might enhance the significant relationship of the financial distress prediction. In that case in the future research, it is suggested that to include qualitative variables such as base lending rate, gross domestic product (Alifiah, 2014), leadership and type of ownership (Tew and Nordin, 2009) which are also imperative in forecasting financial distress in sync with cash flow ratios as a basis of relationship measurement. The combination of the variables might give a different result of the financial distress prediction compared to concentrating on financial ratios only (Tew and Nordin, 2006).

\section{References}

Adibah Wan Ismail, W., Adzrin Raja Ahmad, R., Anuar Kamarudin, K., \& Yahaya, R. (2005). Corporate failure prediction: An investigation of PN4 companies. Journal of Financial Reporting and Accounting, 3(1), 1-16. https://doi.org/10.1108/19852510580000334

Alifiah, M. N. (2014). Prediction of Financial Distress Companies in the Trading and Services Sector in Malaysia Using Macroeconomic Variables. Procedia-Social and Behavioral Sciences, 129, 90-98. https://doi.org/10.1016/j.sbspro.2014.03.652

Altman, E. I. (1968). Financial ratios, discriminant analysis and the prediction of corporate bankruptcy. The Journal of Finance, 23(4), 589-609. https://doi.org/10.1111/j.1540-6261.1968.tb00843.x

Altman, E. I., Haldeman, R. G., \& Narayanan, P. (1977). Zeta tm analysis a new model to identify bankruptcy risk of corporations. Journal of Banking \& Finance, 1(1), 29-54. https://doi.org/10.1016/0378-4266(77)90017-6

Andrade, G., \& Kaplan, S. N. (1998). How costly is financial (not economic) distress? Evidence from highly leveraged transactions that became distressed. The Journal of Finance, 53(5), 1443-1493. https://doi.org/10.1111/0022-1082.00062

Bae, J. K. (2012). Predicting financial distress of the South Korean manufacturing industries. Expert Systems with Applications, 39(10), 9159-9165. https://doi.org/10.1016/j.eswa.2012.02.058

Beaver, W. H. (1966). Financial ratios as predictors of failure. Journal of Accounting Research, 71-111. https://doi.org/10.2307/2490171 
Bhandari, S. B., \& Iyer, R. (2013). Predicting business failure using cash flow statement based measures. Managerial Finance, 39(7), 667-676. https://doi.org/10.1108/03074351311323455

Brown, K. S. (2012). Cohomology of groups (Vol. 87). Springer Science \& Business Media.

Bursa Malaysia. (2001). Listing Requirements: Practice Notes No. 4. Bursa Malaysia, Kuala Lumpur.

Carslaw, C. A., \& Mills, J. R. (1991). Developing ratios for effective cash flow statement analysis. Journal of Accountancy, 172(5), 63.

Fawzi, N. S., Kamaluddin, A., \& Sanusi, Z. M. (2015). Monitoring Distressed Companies through Cash Flow Analysis. Procedia Economics and Finance, 28, 136-144. https://doi.org/10.1016/S2212-5671(15)01092-8

Frank, R., \& Urbancic, D. B. A. (2005). The power of cash flow ratios. Department of Accounting, Mitchell College of Business University of South Alabama. Alabama.

Gravetter, F. J., \& Wallnau, L. B. (2000). Statistics for Behavaioral Sciences (5th ed.). USA: Wadsworth Pub. Co.

Grice, J. S., \& Ingram, R. W. (2001). Tests of the generalizability of Altman's bankruptcy prediction model. Journal of Business Research, 54(1), 53-61. https://doi.org/10.1016/S0148-2963(00)00126-0

Hassan, H. S., \& Alanazi, T. M. (2018). Roles of Islamic Business Ethics in the Formation of Internal Organisational Culture: A Qualitative Approach of Muslims' SMEs in the UK. International Journal of Economics, Business and Management Studies, 5(1), 16-30. https://doi.org/10.20448/802.51.16.30

Hossain, M. A., Hossain, M. S., \& Jahan, N. (2018). Predicting Continuance Usage Intention of Mobile Payment: An Experimental Study of Bangladeshi Customers. Asian Economic and Financial Review, 8(4), 487-498.

Hsiao, C. M., Zhang, W. F., Chiu, C. C., Huang, J. C., \& Huang, Y. L. (2017). The Enterprise Risk Management of Foreign Exchange Exposures: Evidence from Taiwanese Hospitality Industry. Asian Journal of Economics and Empirical Research, 4(1), 32-48. https://doi.org/10.20448/journal.501.2017.41.32.48

Ibarra, V. C. (2009). Cash flow ratios: Tools for financial analysis. Journal of International Business Research, 8.

Inusah, N. (2018). Toda-yamamoto granger no-causality analysis of stock market growth and economic growth in ghana. Journal of Accounting, Business and Finance Research, 3(1), 36-46. https://doi.org/10.20448/2002.31.36.46

Islam, S., Nahar, T. N., Begum, J., Khatun, M., \& Hossain, M. I. (2018). Marketing and Financial Analysis of Milk Production-A Value Chain Perspective. Asian Development Policy Review, 6(1), 32-40. https://doi.org/10.18488/journal.107.2018.61.32.40

Khaliq, A., Altarturi, B. H. M., Thaker, H. M. T., Harun, M. Y., \& Nahar, N. (2014). Identifying financial distress firms: A case study of Malaysia's Government Linked Companies (GLC). International Journal of Economics, Finance and Management, 3(3), 141-150.

Khong, L. Y., Low, C. S., Tee, L. P., \& wan Lim, L. (2015). Corporate failure prediction in Malaysia. Journal of Research in Business, Economics and Management, 4(2), 343-375.

Mills, J., \& Yamamura, J. H. (1998). The power of cash flow ratios. Journal of Accountancy, 186(4), 53.

Myers, S. C. (1977). Determinants of corporate borrowing. Journal of Financial Economics, 5(2), 147-175. https://doi.org/10.1016/0304-405X(77)90015-0

Ng, S. T., Wong, J. M., \& Zhang, J. (2011). Applying Z-score model to distinguish insolvent construction companies in China. Habitat International, 35(4), 599-607. https://doi.org/10.1016/j.habitatint.2011.03.008

Ong, S. W., Choong Yap, V., \& Khong, R. W. (2011). Corporate failure prediction: a study of public listed companies in Malaysia. Managerial Finance, 37(6), 553-564. https://doi.org/10.1108/03074351111134745

Opler, T. C., \& Titman, S. (1994). Financial distress and corporate performance. The Journal of Finance, 49(3), 1015-1040. https://doi.org/10.1111/j.1540-6261.1994.tb00086.x

Outecheva, N. (2007). Corporate financial distress: An empirical analysis of distress risk. Doctoral dissertation, University of St. Gallen.

Pallant, C. (2011). Demystifying Disney: A History of Disney Feature Animation. Bloomsbury Publishing USA. https://doi.org/10.5040/9781628928655

Pallant, J. (2005). SPSS survival guide. Crow's Nest, NSW: Allen \& Unwin. 
Purnanandam, A. (2008). Financial distress and corporate risk management: Theory and evidence. Journal of Financial Economics, 87(3), 706-739. https://doi.org/10.1016/j.jfineco.2007.04.003

Rim, E., \& Roy, A. (2013). Classifying Manufacturing Firms in Lebanon: An application of Altman's Model. 2nd World Conference on Business, Economics and Management-WCBEM (pp. 11-18). https://doi.org/10.1016/j.sbspro.2013.12.413

Rodgers, C. S. (2011). Predicting corporate bankruptcy using multivariate discriminate analysis (MDA), logistic regression and operating cash flows (OCF) ratio analysis: A cash flow-based approach. Golden Gate University.

Roslan, N. H. B. (2014) Determinants of financial distress among manufacturing companies in Malaysia. Doctoral dissertation, School of Business, Universiti Utara Malaysia.

Ryu, K., \& Jang, S. (2004). Performance measurement through cash flow ratios and traditional ratios: A comparison of commercial and casino hotel companies. The Journal of Hospitality Financial Management, 12(1), 15-25. https://doi.org/10.1080/10913211.2004.10653783

Schwartz, A. (2005). A normative theory of business bankruptcy. Virginia Law Review, 1199-1265.

Sekaran, U., \& Bougie, R. (2013). Research Methods for Business: A Skill-Building Approach (6th ed.). Jhon Wiley and Sons.

Senbet, L. W., \& Wang, T. Y. (2010). Corporate financial distress and bankruptcy: A survey. Foundations and Trends in Finance, 5(4). https://doi.org/10.1561/0500000009

Smith, M., Ahmar Ahmad, S., \& Shameer Mohamed, A. (2004). Modelling PN4 classification among Malaysian listed companies. Asian Review of Accounting, 12(2), 57-73. https://doi.org/10.1108/eb060777

Tew, Y. H., \& Nordin, E. (2006). Predicting corporate financial distress using logistic regression: Malaysian evidence/Tew You Hoo and Enylina Nordin. Social and Management Research Journal, 3(1), 123-132. https://doi.org/10.24191/smrj.v3i1.5108

Wanke, P., Barros, C. P., \& Faria, J. R. (2015). Financial distress drivers in Brazilian banks: A dynamic slacks approach. European Journal of Operational Research, 240(1), 258-268. https://doi.org/10.1016/j.ejor.2014.06.044

Ward, J. (1994). Space-time adaptive processing for airborne radar (No. TR-1015). Massachusetts Inst of Tech Lexington Lincoln Lab.

Yi, W. (2012). Z-score model on financial crisis early-warning of listed real estate companies in China: a financial engineering perspective. Systems Engineering Procedia, 3, 153-157. https://doi.org/10.1016/j.sepro.2011.11.021

Zabala, B. A. Jr., \& Peñol, C. A. Z. (2018). Social Interactive Behavioral Problems of Social Studies Students of Cabiao National High School. Global Journal of Social Sciences Studies Studies, 4(2), 102-114. https://doi.org/10.20448/807.4.2.102.114

Zeni, M., \& Ameer, R. (2010). Turnaround prediction of distressed companies: evidence from Malaysia. Journal of Financial Reporting and Accounting, 8(2), 143-159. https://doi.org/10.1108/19852511011088398 